\title{
The Transformation of the Position of a Woman in the Republic of Turkey in the Twentieth Century
}

\author{
Lola B. Baltaeva ${ }^{1}$ \\ ${ }^{1}$ Kazan (Volga Region) Federal University, Kazan, Russia \\ Correspondence: Lola Batyrbaevna Baltaeva, Kazan (Volga Region) Federal University, 420008, Kremlyovskaya \\ Street, 18, Russia. E-mail: baltaeva.lola@gmail.com
}

Received: June 15, 2015 Accepted: June 24, 2015 Online Published: June 30, 2015

doi:10.5539/jsd.v8n7p61 URL: http://dx.doi.org/10.5539/jsd.v8n7p61

\begin{abstract}
The problem under investigation concerning the emancipation of women in Muslim countries and in the countries where Islam has been a dominant ideology is of great scientific and practical importance in the context of the existing stereotypical vision on the status of women in Muslim society. The purpose of the article is to study the transformation of the position of Turkish women, the change of their role as a result of social, administrative, legal, religious and cultural transformations in the Republic of Turkey in the twentieth century. The leading approach to the study of this problem is a historical-comparative method allowing to trace the development of "women's issue" in the Republic of Turkey on the basis of the activities of the companies and organizations, the decisions allowing to change the status of women at the legislative level, as well as to solve the problems concerning women's education, employment and their participation in political life. The article presents the results showing the strengthening of the position of Islamic feminism in which women having estimated all pros and cons of freedom and equality with men, choose Islamic values, despite the growing "sekulyarizovannost" of the society. The submissions of the article may be useful in the research of gender problems of Islamic societies, as well as in contemporary public debates about the place of women in a secular state in which Islam takes the leading positions.
\end{abstract}

Keywords: feminism, Islamic feminism, Islam, women's social organizations

\section{Introduction}

\subsection{Background}

The processes of globalization in the modern world intensify a cross-cultural interaction, which inevitably entails the participations of the peoples following Islam. The result is a modernization of Islamic society, an obligatory component of which is the review of the traditions associated with gender relations and democratization. Any transformation of the roles of men and women in most cases cause a negative reaction, both in the society and in every individual family, and are accepted as an attack on the inviolability of traditions. Thus, the processes of emancipation and feminization of the Muslim community are considered as something alien, incomprehensible, and therefore dangerous (Lebedev, 2012).

Among Muslim countries, the Republic of Turkey is the most progressive in relation to the rights and freedom of women: today it has a rich experience in solving the problems of constitutional recognition of the equal legal status between women and men and implementation of administrative and organizational measures aimed at providing for women a worthy place in a family, society and state.

However, in Turkey, as in most states with a majority of population following Islam, the questions about the status, rights and duties of women between the representatives of the secular and religious communities have been debating (Kyutyukchyu, 2011).

\subsection{The Status of the Problem}

It is important to note that all the researches during the Soviet period were devoted to the description of a hard life of a Muslim woman under a cruel religious oppression. "Humiliated", "insulted", "disenfranchised", "unhappy", "tortured", "impersonal" are the most frequently used epithets about a Muslim woman in the literature of the first half of the XX century (Venta, 2012). 
In the 80-90-ies of the twentieth century Soviet Orientalists published a large number of works devoted to the analysis of the important role of the Islamic factor in the social and political processes that took place in the East. Soviet researchers paid attention to the position of women in Muslim society. The results of their works are reflected in the collections devoted to the research of socio-economic, political and cultural life of the Islamic states. In the published articles the role of women in these spheres of social life was also under consideration but often for the sake of Soviet ideology, many facts were reported in isolation from the historical context and were used as a basis for the vulgar sociological criticism (Salimov, 1990). In the XXI century in different parts of the former Soviet Union the experts on Islam came to the point of view that in the modern public consciousness a distorted image of the "enslaved" Muslim woman was still dominant (Frolov, 2009).

The intensification of the study of the role of women in Muslim society is observed on the examples of the life of Turkish women. All this is the result of the achievements of the Turkish Republic inside the country and on the international level. The country attracts more and more attention and the interest to the life of people of so rapidly developing state is a consequence of these processes.

\section{Methodological Framework}

\subsection{The Objectives of the Research}

In this research the following tasks were solved: 1) the study of "women's issue" in the Republic of Turkey on the basis of the activities of the companies and organizations, the decisions allowing to change the status of women at the legislative level, 2) the study of the development of women's education; 3) the study of the problem of employment of women in Turkey in the twentieth century; 4) the analysis of the place of Turkish women in the family and in society; 5) the study of the position of Turkish women in a political life of the country; 6 ) the study of the problem of the hijab wearing in Turkey in the twentieth century.

\subsection{Theoretical and Empirical Methods}

Scientific and theoretical methods of analysis and synthesis as well as special empirical methods (statistics, a historical and comparative method) are used in the research.

\subsection{The Basis of the Research}

As the basis of the research there were taken women's social organizations, newspapers and magazines in Turkey of the twentieth century, as well as biographies and works of the founders of these organizations and other progressive women of their time who were a good example for a new still deeply patriarchal world of ideas aimed at combating with "secondary "position of Turkish woman in Turkish society.

\subsection{The Stages of the Research}

The research was conducted in three stages:

On the first stage, some of the most successful Turkish women's social organizations and magazines were selected. Here we can mention the magazine "Women's World» («Kadınlar Dünyası»), «Social protection of the rights of women» («Müdafaa-i Hukuk-i Nisvan Cemiyeti»), «Society for the advancement of women» («Teali-i Nisvan Cemiyeti») and "Union of Turkish women» («Türk Kadınlar Birliği»).

On the second stage, on the basis of the published sources and programs of organizations the goals as the basis of the activity of different unions or magazines and outstanding ideologists such as Nuriye Ulviyya Dzhivelek Mevlana Khalid Edib Adyvar, Nezihe Mukhiddin, Latife Bekir (Cheyrekbashy) Sabiha Zekeriye (Sertel) Latife Bekir Cheyrekbashy, Makbule Dyblan, Mebrure Aksol, Camille Erim, Neriman Sirer, Aliya Beyazit, Lamia Refik Fenmen, Mediha Elda Necil bilen and others were singled out.

On the third stage the analysis of the achievements of these organizations was carried out.

\section{Results}

\subsection{The Achievements in the Political and Legal Sphere}

Due to the efforts of activists and according to the Civil Code adopted in 1926, a woman acquired the status of personality, women were given the equal rights with men to act as witnesses in the court, and in 1930 according to the constitution they could have the right to take part in the municipal elections. In 1933, women gained the right to elect and be elected to the Board of village elders, and a year later, in 1934, women won the right to join the Turkish Grand National Assembly (TBMM).

The first Congress of the World Union of Women was organized by the Union of Turkish women in 1935. In the same 1935 according to the results of the elections of deputies of the fifth convocation 18 women deputies were elected in the Majlis; the goals were achieved and a Turkish Women's Union was dissolved . 
Since 1986, Turkey is a participant of the Convention on the Elimination of All Forms of Discrimination against Women (CEDAW- Convention to Eliminate All Forms of Discrimination against Women), adopted in 1979.

\subsection{The Achievements in the Field of Women's Education and Employment}

In 1897, women systematically seeking for a greater role in public life were first accepted for the paid work; in order to be admitted to the civil service, it took them another 16 years. In a year women were allowed to work in the sphere of trade and crafts.

On September 12, 1914 there was an official opening of the so called "Women's University» («Inas Darülfünun»). A women's university was preceded by delivering free lectures for women,organized on February 7, 1914. These lectures were very popular: in the conference hall of the mansion named Zeynep Hanim 600-700 women gathered together. The lectures were given on such subjects as mathematics, cosmography, physics, history, etiquette, hygiene, women's rights, physical education, etc.. The lecturers were such prominent people of Turkey as : Professor of Medicine Besim Omer Akalin, a historian, a lawyer, a writer and a poet Ahmet Cevdet Pasha, Minister of Justice Mahmut Esat Bozkurt, a writer and a political analyst Ismail Hakki Baltadzhyoglu and others (Arslan, 2005).

On November 1, 1914 a School of Fine Arts for Women (İnas Sanayi-i Nefise Mektebi) was opened in the main building of Istanbul University. In 1914, the first seven Muslim women were taken to work at the phone company (Islam, 1990), that means that they were taken as service workers. In 1921 seven girls attending classes in charshafah, were taken to the Medical Faculty of Istanbul University.

However, the social conditions, the level of consciousness of people and the political situation remained the same and the urgency of the problems concerning women's issue was on the same level. "No changes in the status of women were possible," - claimed "opposition groups", consisting of the opponents of women's emancipation - Islamists, turanists and itilyafists. Especially vigorously defended their interests Islamists considering a change in the status of women as derogation from "Allah's laws."

At the beginning of the twentieth century the Republican government took a number of important events that resulted in the secularization of the state system, that brought to a drastic restriction of the Islamic religion in public and political life of the country. The Constitution of 1934 enshrined the principles of the secular character of the state (Islam, 1990).

Special fatwa forbade coeducation of boys and girls, but in spite of it the dean of the Faculty of literature at Istanbul University issued the Act of coeducation in 1921 (Rustamov, 1980).

At the beginning of the XXI century Ministry of National Education made special efforts to create an educational system free of conventions.

Due to the efforts in this field instead of the usual image of a woman as a representative in her traditional occupation or playing a minor role, the emphasis was made on successful women playing an active role in society, and equal distribution of duties between men and women at work and in the family. In the textbooks for a primary school a Turkish concept «bilim adamı», that means "man scientist" is replaced by gender-neutral expression «bilim insanı» (scholar); there were added the pictures of women - athletes, engineers, scientists. Besides, in the textbooks for primary schools the images of women voting at the polling stations, women mayors and district governors are given (Sixth, 2008).

As for the employment of women, in spite of the introduction of all the transformations and programs of the XX century into the all spheres of the society, by the beginning of the XXI century the proportion of women and men as labour force remained incommensurable, they are still significantly different according to the following table.

Table 1. The proportion of workers (aged 15 and over) by sex in urban and rural areas (in percentage) (Turkiye, 2007)

\begin{tabular}{lll}
\hline & Urban population & \\
\hline & 2000 & 2006 \\
\hline Males & 70.9 & 70.8 \\
Women & 17.2 & 19.9 \\
& Rural population & \\
Males & 77.9 & 72.7 \\
Women & 40.2 & 33 \\
\hline
\end{tabular}


Low employment rates are mainly caused by an extremely low percentage of women, especially urban, as labour force. The most significant reason for this phenomenon is a migration from the countryside to the cities. A rural population in Turkey gradually decreases and the population and economic potential of cities increases. In Turkey, where the urbanization of society takes place, women who previously worked in the countryside unpaid feel difficulties in finding a place in the urban labor market, even if they have the same with men level of education and qualification. The absence of the necessary level of qualification required on the urban labour market, duties and obligations performed by women in the family and restrictions of a family and social character are the main reasons of this process.

Table 2. The share of workers (at the age of 15 and older), depending on the level of education (in percentage) in 2000 (Turkiye, 2007)

\begin{tabular}{ll}
\hline Men & $\mathbf{\%}$ \\
\hline Illiterate & 56,7 \\
Education below the average of & 74,9 \\
Secondary education and vocational education & 70,8 \\
Education at Colleges and Universities & 83,2 \\
Women & $\mathbf{\%}$ \\
Illiterate & 25,2 \\
Education below the average of & 23,0 \\
Secondary education and vocational education & 31,8 \\
Education at Colleges and Universities & 70,1 \\
\hline
\end{tabular}

According to the table higher education plays a significant role in involving women into the labour market. Despite the fact that women-graduates of the universities who live in the cities represent a non-significant share of urban women's population, their share as a labour force is much higher than the share of women who finished a primary school and represents half of the urban women's population ( $70 \%$ and $13 \%)$. It should be noted that marriage negatively influences the imployment of women, in particular, the women with a low level of education. Unmarried urban women have higher characteristics of imployment in comparison with married ones. For example, the share of unmarried urban women as labour force was 35\% in 2006 and the appropriate share of married women was $15 \%$ (Shestoy, 2008). This situation contradicts to the right on a free choice of profession and kind of activity; besides, according to the Civil code the spouse should not ask each other for permission what type of activity and profession to choose (Turk,2001).

\subsection{The Achievements in the Area of Family Relations}

Women's organizations demanded to abolish the isolation of women from society, to give the right to education, to prohibit polygamy and underage marriage of girls, to legalize a civil marriage code, to cancel humiliating the dignity of women "talaq" during divorce, (an exclusive right of men to carry out a unilateral divorce by pronouncing divorce formula three times) as a symbol of the absolute power of men over women. However, these claims of women's organizations were rejected by the Commission of Religious Affairs of the Turkish government on condition that the Muslim laws requiring marital consent of the bride, giving women the right to divorce and canceling or restricting polygamy, that is, all the requirements of Islam, which were intended to preserve balance in gender roles were of purely "symbolic" value. Meanwhile there were made some concessions, concerning the issues of polygamy. The permission for the second marriage could be given only when the court would receive the evidence of admissibility of the marriage within the laws of sharia (Khadduri, 1978).

In 1917, the Decree on Family Law (Hukuk-u Aile Kararnamesi) introduced the marriage into the legal sphere, gave women the right to divorce and the permission of the first wife gave the way to polygamy. All these changes in most cases did not have a real power, but the fact of their acception meant a significant step forward.

In 1926, there was a new civil code accepted, aimed at realization in practice the idea of Ataturk who proclaimed the equality of men and women. The law of marriage and family relations based on the provisions of the Civil Code banned polygamy, introduced a civil marriage instead of religious, accepted equal rights of a father and a mother in the questions of upbringing children and in matters of inheritance. A new law set the minimum age of 
marriage: 19 years for men and 16 years for women. This brought to the process of decreasing of early marriages (Abadan-Unat, 1979).

The Turkish constitution of 1934 proclaimed the principle of equality between women and men. Maternity was recognized as a social function. The government assumed the protection of the family, the creation of social institutions designed to protect maternity and childhood (Kadınların, 1974).

\section{Discussions}

The most complete, comprehensive coverage of the unique experience of the Turkish Republic about constitutional recognition of equality of men and women contain the works of Imam-Khatib of the Moscow Cathedral Mosque, PhD Mustafa Kyutyukchyu (2010). However, his work focuses on the basic philosophical and cultural analysis of women's rights in the system of human rights and her position in the family, society and state in the countries and regions of traditional spreading of Islam. A great contribution to the development of the subject was also made by the researcher Yousif Rustamov (1980), president of the Gender Studies Emel Dogramaci (1989), Professor of Istanbul University Fatmagyul Berktay (2004), Professor of the Institute of Contemporary History of Turkey after Ataturk Zafer Toprak (2000), candidate of political sciences Serpil Cakir (2010) and others.

\section{Conclusions}

The paradox of the situation of the majority of Turkish women was the fact that, although according to the law they had all rights but in fact, there were no serious changes in their life. As a result of the traditional attitude towards women employers did not appoint women for higher positions, they did not allow them to develop their qualification, most women could get only traditionally "feminine" professions. Women's rights were violated not only when applied for a job, but also when they were paid for their job. The International Convention of 1951 on the equality of payment did not make any impact on changing the status of working women. The largest category of working women was employed in the agricultural sector, where the rate of exploitation was particularly great.

On the basis of this work it can be concluded that all the reforms performed by Kemalists were limited by different aspects of social life, without affecting the basis of social relations, especially in rural areas where the majority of women did not know and did not hear about their rights according to the civil code, because over $70 \%$ of the female population was illiterate.

The woman's issue about her rights and opportunities is still very urgent. Turkey, as a participant of the Convention on the Elimination of Discrimination against Women (1986) takes all the appropriate measures concerning the problems of marriage and family relations on the basis of equality of men and women. In this regard, in 2002, a new Civil Code entered into force and provided the following rights:

a) the equal rights in entering the marriage;

b) the equal rights in choosing a spouse and entering the marriage with marital consent;

c) the equal rights and responsibilities during marriage and its dissolution;

d) the equal rights and responsibilities of parents, irrespective of their marital status, in matters relating to their children;

e) the equal rights to decide freely and responsibly the question about the number of their children and have an access to the information, education and means for implementation of these rights;

f) the equal rights and responsibilities with regard to guardianship, custodianship, trusteeship and adoption of children or similar institutions.

g) the equal personal rights of a husband and a wife, including the right to choose a family name, a profession and an occupation;

h) the equal rights for both spouses in respect to the ownership, acquisition, management, use and disposal of the property.

According to the Civil Code of Turkey, the official registration of marriage is compulsory, those who enter the marriage by a religious ceremony without official registration are prosecuted.

An interesting fact is that until 1996 a breach of faith was recognized as an offense. In 1996, the Constitutional Court amended Article 441 of the Criminal Code, since that a breach of faith came out of the scope of criminal liability. Two years later, in 1998, similar amendments related to women-activists were introduced.

Among the Muslim countries and countries with a predominantly Muslim population, Turkey today is the most 
progressive in overcoming gender inequality as a result of the actions of women's organizations which existed in the last decades of the Ottoman Empire and the first decades of the Turkish Republic. The prominent women of their time in spite of the male hegemony in all spheres of society, despite the lack of understanding and lack of support of their ideas by the majority even of the female population, solved a lot of urgent problems and succeeded in it. They became a good example for women who were dissatisfied with their position in the family and society. As soon as the key tasks set up by women's organizations were solved, the activity of the feminist movement went into decline. Today a Turkish woman is legislatively protected from any harassment and discrimination based on gender, she has the same rights as a European woman and the activity of women's organizations of today is to convey information about the rights to the women in rural areas, urban slums, and women who did not get education.

\section{Acknowledgments}

The work is performed according to the Russian Government Program of Competitive Growth of Kazan Federal University.

\section{References}

Abadan-Unat, N. (1979). Toplumsal değişme ve Türk kadını (1926-1976). Türk Sosyal Bilimciler Derneği Kadın Araştırması Serisi. Ankara, Çağ Matbaası.

Abadan-Unat, N. (1981). Woman in Turkish society. Leiden, E.J. Brill.

Arslan, A., Akpınar, Ö. (2005). İnas Darülfünunu (1914-1921) Osmanlı Bilimi Araştırmaları VI / 2, 225 -234.

Berktay, F. (2004). Kadınların insan haklarının gelişimi ve Türkiye. Sivil Toplum ve Demokrasi, Konferans Yazıları No.7, 8-10.

Çakır, S. (2010). Osmanlı kadın hareketi. İstanbul, Metis Yayınları.

Doğramacı, E. (1989). Türkiye'de kadının dünü ve bugünü. Ankara, Türkiye İş Bankası Kültür yayınları.

Frolova, L. V. (2009). Status zhentchiny v islame. Vestnik. Adyg.gos. Univ. Seriya.:Filosifiya, Istoriya, sociologiya, yurisprudentsiya, politologiya, kulturologiya, 2, 148-154.

İstanbul Kadın Müzesi. Retrieved from http://www.istanbulkadinmuzesi.org/darulmuallimat

Kadınlara yönelik yasal düzemlemeler. Kadem Kadın ve demokrasi derneği. Retrieved from http://kadem.org.tr/kadinlara-yonelik-yasal-duzenlemeler/

Kadınların sesi. (1974). 4, 3-4.

Khadduri, M. (1978). Marriage in Islamic law: The modernist viewpoints. The American Journal of Comparative Law, 26(2). http://dx.doi.org/10.2307/839669

Kyutyukchyu, M. (2010). Istoriko-kulturologicheskiye predposylki formirovaniya kontseptualnogo podkhoda $\mathrm{k}$ polozheniyu zhentchiny v turetskom obtchestve.Gosudarstvo, religiya, tserkov v Rossii I za rubezhom. № 1 . Moskva, Izdatelstvo RAGS.

Kyutyukchyu, M. (2011). Islamskaya zhentchina v sovremennoy Turtsii. (Unpublished master's thesis). RAGS pri presidente Rossiiskoy Federatsii, Moskva.

Lebedeva, I. V. (2012). Svobodnaya zhentchina vostoka kak fenomen “drugogo” v sem'ye. Astrakhanskiy Gosudarstvennyi Universitet. Retrieved from http://www.kaspy.aspu.ru/files/4(33)/302-309.pdf

Rustamov, Y. I. (1980). Islam i obtchestvennaya mysl'sovremennoi Turtsii. Baku, Institut Filosofii i Prava.

Salimov, F. S. (Eds.). (1990). Islam i zhentchiny vostoka: Istoriya i sovremennost'. Tashkent, Institut Vostokovedeniya imeni Abu Rayhana Biruni.

Sixth periodic report of Turkey, prepared for consideration by the Committee on the Elimination of Discrimination against Women. (2008). Ankara. Retrieved from http://www.refworld.org.ru/docid/49a7e80a2.html

T. C. Milli eğitim bakanlığı. Retrieved from http://mebk12.meb.gov.tr/meb_iys_dosyalar/41/01/332717/icerikler/ leyla-atakan-kimdir_54708.html

TC Başbakanlık Atatürk kültür, dil ve tarih yüksek kurumu «Türk tarih kurumu». Retrieved from http://www.ttk.gov.tr/

Toprak, A. Z. (2000). Muslihiddin Adil'in görüşleri: Kadın ve «Hukuk-1 Nisvan». Toplumsal Tarih, 75, 14-18. 
Turkiye istatistik kurumu TÜiK. (2007). Retrieved from http://www.turkstat.gov.tr/

United Nations Entity for Gender Equality and the Empowerment of Women. Retrieved from http://www.un.org/womenwatch/daw/cedaw/

Venta, R. (2012). Evolutsiya obrasa musulmanki $\mathrm{v}$ issledovaniyakh XX-XXI vekov. Zhentchina $v$ rossiiskom obtchestve, $\quad 1, \quad 81-88$. http://womaninrussiansociety.ru/wp-content/uploads/2013/11/2012_1_venta.pdf

Women in Turkey. Their struggle for peace and equality. Solidarity committee for women's rights in Turkey. (1985). London.

\section{Copyrights}

Copyright for this article is retained by the author(s), with first publication rights granted to the journal.

This is an open-access article distributed under the terms and conditions of the Creative Commons Attribution license (http://creativecommons.org/licenses/by/3.0/). 